\title{
MEMBANGUN PARIWISATA BERSAMA RAKYAT: KAJIAN PARTISIPASI LOKAL DALAM MEMBANGUN DESA WISATA DI DIENG PLATEAU
}

\author{
Destha Titi Raharjana \\ Pusat Studi Pariwisata Universitas Gadjah Mada \\ Email: raharjanadestha@yahoo.co.id
}

\begin{abstract}
Development as a process of life change should involve communities as intergral elements. People should not only be regarded as objects of development. The paradigm of the bottom up planning expects people to act as both the subject and object of development. In the context of the development of rural tourism, the planning process should involve the local communities from the beginning. Dieng Plateau as a tourist site has a diversity of attractions, and tourist-oriented villages are designed by local communities to complement the tourist attractions in Dieng. This Study focuses on the participation of the communities in western Dieng in developing tourist villages in their area.Various stages of the planning are completed collectively and then put into action together. By applying action research methods, this study has the following results: (1) the identification of problems in the development of rural tourism, (2) the mapping of the potential of rural tourism, and (3) the identification of potential inter-agency networking to support sustainable rural tourism in western Dieng.
\end{abstract}

Keywords: Community, Participation, Tourism, Rural Tourism, Dieng Plateau

\begin{abstract}
ABSTRAK
Pembangunan yang dipahami sebagai proses perubahan di dalam kehidupan semestinya melibatkan masyarakat sebagai unsur yang tidak terpisahkan. Masyarakat sebaiknya tidak dipandang sebagai objek pembangunan semata. Adanya paradigma bottom up planning mengharapkan masyarakat dapat berperan sebagai subjek sekaligus objek pembangunan. Dalam konteks pembangunan desa wisata, dalam proses perencanaan harus sejak awal melibatkan masyarakat lokal. Dataran Tinggi Dieng sebagai objek wisata memiliki keragaman atraksi. Desa wisata dirancang oleh masyarakat setempat untuk melengkapi atraksi wisata di Dieng. Kajian ini menfokuskan pada proses partisipasi masyarakat Dieng Kulon dalam membangun desa wisata di lingkungan tempat tinggal mereka. Berbagai tahapan perencanaan dikerjakan secara kolektif dan kemudian dipraktekkan bersama-sama. Dengan menerapkan metode action riset, studi ini menemukan beberapa temuan berikut: (a) identifikasi masalah-masalah dalam pengembangan desa wisata, (b) pemetaan potensi desa wisata, dan (c) identifikasi potensi jejaring antar lembaga yang dapat mendukung keberlanjutan desa wisata di Dieng Kulon.
\end{abstract}

Kata Kunci: Masyarakat, Partisipasi, Pariwisata, Desa Wisata, Dataran Tinggi Dieng 


\section{PENGANTAR}

Kawasan Dataran Tinggi Dieng memiliki pesona wisata nan eksotis. Berada diketinggian $2.100 \mathrm{mdpl}$ dengan landscape yang mempesona menjadikannya sebagai pilihan tempat istirahat zaman kolonial hingga sekarang. Udaranya yang sejuk, lingkungan alami didukung ragam potensi alam dan budayanya mampu menyihir orang untuk datang. Asal kata Dieng berasal dari bahasa Sansekerta yaitu "Di" yang berarti tempat yang tinggi atau gunung dan "Hyang" yang berarti kahyangan. Dari penggabungan kata tersebut, maka dapat diartikan bahwa "Dieng" merupakan wilayah yang tinggi berupa pegunungan tempat para dewa dan dewi bersemayam (Sukatno, 2004).

Di abad VIII sampai XII Masehi, telah dibangun kompleks percandian seluas $900.000 \mathrm{~m}^{2}$ (Sonjaya, 2005). Kompleks candi Dieng terdiri dari Candi Arjuna, Candi Dwarawati, Candi Gatot Kaca, dan Candi Bima. Kompleks Candi Arjuna terdiri dari Candi Arjuna, Candi Semar, Candi Srikandi, Candi Puntadewa, dan Candi Sembadra. Komplek Candi Dieng dibangun pada masa agama Hindu, hal ini dapat dilihat dari peninggalan Arca Dewa Siwa, Wisnu, Agastya, dan Ganesha. Semuanya bercirikan Agama Hindu. Candi-candi di Dieng dipercaya sebagai tanda awal peradaban Hindu di Pulau Jawa pada masa Sanjaya pada abad ke-8. Hal ini ditunjukkan dengan adanya gugusan candi di Dieng yang konon untuk memuja Dewa Syiwa. Candicandi tersebut antara lain: Candi Arjuna, Candi Srikandi, Candi Puntadewa, Candi Sembadra, Candi Gatot Kaca. Sedangkan untuk penamaan candi-candi itu sendiri dipercaya baru dimulai pada abad ke-19.

Di kawasan Dieng ini pula sumber mata air Sungai Serayu bermula. Sungai Serayu merupakan sungai yang mengalir di Jawa Tengah bagian Selatan dan bermuara di Cilacap. Bukan itu saja keunikan kawasan Dieng sebagai daerah vulkanik ditandai banyaknya kawah aktif dan diolah sebagai geothermal. Yaitu eksplorasi panas bumi di kawasan Dieng dilakukan PT Geodipa Energi.
Dieng Plateau pada zamannya memiliki ekosistem yang unik. Sayangnya, kondisi saat ini sudah berubah. Gambaran indah tempo dulu sudah tidak dapat lagi dijumpai. Ekosistem Dieng telah berubah. Bencana akibat kerusakan lingkungan mendera kawasan yang dulu dikenal sebagai daerah tangkapan air. Pasca-Reformasi perambahan hutan dan kawasan perbukitan terus terjadi akibat tekanan penduduk terhadap lahan yang sangat tinggi (Kedaulatan Rakyat, 16/4/2008). Hal ini diperburuk lagi dengan budidaya pertanian monokultur berupa kentang, sehingga erosi di hulu sangat besar. Beberapa sungai menjadi keruh dan menimbulkan sedimentasi pada hilirnya. Selain itu, terjadi penyusutan debit air secara tajam ketika musim kemarau (Kompas, 3/4/2010) dan pada musim penghujan ditandai dengan banjir besar. Banjir bandang Januari 2000 merupakan dampak nyata dari salah kelola lingkungan. Tidak ada yang menyangka bahwa daerah pegunungan yang berada di ketinggian 2.000 meter $\mathrm{dpl}$ dapat diterjang banjir bandang. Musibah itu diakibatkan oleh rusaknya hutan lidung dan puncak Gunung Perahu karena ulah masyarakat (Suara Merdeka, 20/12/2004). Kedaulatan Rakyat (13/3/2003) mewartakan petani dilarang menanam kentang di dataran tinggi. Pihak Perhutani Kedu Utara bersama Lembaga Masyarakat Desa Hutan (LMDH) juga mengeluarkan larangan yang sama bagi petani di Dieng dan memberi jalan lain kepada mereka agar menanam kopi atau salak pondoh di sela-sela tegakan. Kompas (3/4/2010) mengabarkan bahwa saat ini telah tumbuh kesadaran petani untuk memulihkan kondisi lingkungan di Dieng melalui penanaman lima ribu bibit pohon eukaliptus yang cepat tumbuh, dapat menyimpan air, serta bernilai ekonomis tinggi. Selain penyelamatan ekosistem Dieng lewat kaidahkaidah konservasi alam, saat ini diupayakan untuk memberi kesadaran pengembangan pariwisata sebagai penyelamat ekosistem Dieng (Kompas, 23/12/2009).

Semenjak krisis ekonomi melanda Indonesia popularitas Dieng menurun hingga 
awal dekade 2000-an. Sejak itu tampak usaha masyarakat Dieng untuk mengolah aset wisatanya yang sempat terabaikan. Sebagian warga mulai mencari solusi dengan mengembangkan jasa pariwisata di desanya, seperti menyisakan ruang kamar untuk disewakan kepada wisatawan sebagai rumah inap, meskipun mereka juga tetap berprofesi sebagai petani kentang demi kebutuhan ekonomi keluarga. Salah satunya yang dijalankan warga di Dieng adalah mengonservasi alam Dieng dengan aktivitas baru lewat jasa wisata sebagai alternatif mengurangi dampak perusakan ekologis, sekaligus memberdayakan masyarakat lokal sambil tetap menjaga kelestarian budaya. Pariwisata dipandang sebagai satu alternatif sebab pengembangan kawasan wisata dapat melestarikan objek wisata, mendorong pelestarian alam, dan transformasi ekonomi menuju ekonomi berbasis jasa.

World Tourism Organization (WTO) pada 1995 menunjukkan bahwa telah muncul perkembangan pariwisata alternatif yang dipandang lebih menghargai lingkungan dan juga kebudayaan masyarakat lokal. Kenyataan tersebut kini memicu kesadaran pembangunan pariwisata yang berwawasan lingkungan sebagai "alternative tourism" (Smith dan Eadington, 1992; Weiler dan Hall, 1992). Pariwisata alternatif dimengerti sebagai pariwisata yang mempertimbangkan pemanfaatan sumber daya alam saat ini untuk generasi mendatang, seperti green tourism; soft tourism; low-impact tourism; eco-tourism; responsible tourism; sustainable tourism; dan lain-lain (Hunter \& Green, 1995 dalam Paramita, 1998; Mowforth dan Munt, 1998:156-186). Orientasi pembangunan kepariwisataan perlu menempatkan fakta di atas sebagai pertimbangan pokok dalam menumbuhkembangkan kapasitas dan kapabilitas pada masyarakat (Beeton, 2006). Hal ini dilakukan untuk dapat meningkatkan pelayanan sekaligus merealisasikan peran sentral masyarakat dalam aktivitas pembangunan kepariwisataan sesuai dengan harapan dan kemampuan yang dimiliki. Partisipasi masyarakat dirasa penting untuk mengambil keputusan dalam pembangunan kepariwisataan maupun manfaat yang akan diterima sebagai implikasi berlangsungnya aktivitas wisata di kawasan pedesaan (Wall, 1995). Di Indonesia pengembangan desa wisata lebih banyak difasilitasi negara, sedangkan masyarakat cenderung pasif. Akibatnya, kapasitas lokal di dalam merespon inovasi yang disponsori oleh negara melalui pembangunan desa wisata masih menghadapi sejumlah persoalan krusial (Damanik, 2009:131-133).

Di tingkat global, aktivitas wisata secara massif yang berjalan selama ini dipercaya memunculkan dampak negatif, ditandai dengan berlangsungnya penurunan kualitas lingkungan yang sering dijamah wisatawan (Paramita, 1998). Ada dua hal pokok yang dapat diasumsikan sehubungan dengan pariwisata dan lingkungan. Pertama, lingkungan akan terganggu oleh aktivitas wisata. Tourism dan lingkungan terus berdialektika, yaitu dalam wujud pertentangan atau konflik. Kedua, lingkungan dan pariwisata saling bersinergi dan saling mendukung satu sama lain. Anggapan kedua ini hanya dapat dilakukan apabila stakeholders menyadari bahwa kualitas lingkunganlah yang menjadi dasar nilai jual untuk wisatawan. Dataran tinggi Dieng sebagai kawasan wisata telah mengalami tekanan lingkungan, sehingga upaya pemahaman dampak ekologi sangat mendesak dilakukan. Informasi ekologi menjadi sangat penting bagi pengelola guna mengetahui dinamika kawasan. Informasi ini pada gilirannya bermanfaat untuk menyusun langkah perencanaan pariwisata, seperti perencanaan desa wisata kawasan dataran tinggi Dieng. Desa wisata merupakan suatu wilayah perdesaan yang dapat dimanfaatkan berdasarkan kemampuan unsur-unsur yang memiliki atribut produk wisata secara terpadu, di mana desa tersebut menawarkan secara keseluruhaan suasana yang memilikan tema dengan mencerminkan keaslian pedesaan, baik dari tatanan segi kehidupan sosial budaya dan ekonomi serta adat istiadat keseharian yang mempunyai ciri khas arsitektur dan tata ruang desa menjadi 
suatu rangkaian aktivitas pariwisata (www. wikipedia.org,2010).

Keterlibata warga dalam pengembangan desa wisata menjadi hal yang penting karena dari wargalah yang lebih mengetahui dan memahami akan potensi wilayahnya. Selain itu, keterlibatan warga ini sangat penting untuk mendapatkan dukungan dan memastikan bahwa hal yang akan diperoleh selaras dengan kebutuhan dan keuntungan wargasetempat.Akhirnya, peranwargadalam pembangunan pariwisata sangat mendesak untuk dikembangkan dan ditempatkan sebagai bagian yang terintegrasi. Partisipasi masyarakat hakikatnya bukan semata mendorong terjadinya proses penguatan kapasitas masyarakat lokal, tetapi merupakan sebuah mekanisme guna meningkatan pemberdayaan bagi warga untuk terlibat dalam pembangunan secara bersama. Dalam konteks pembangunan pariwisata tampaknya partisipasi masyarakat penting untuk terus didorong guna mendistribusi keuntungankeuntungan dari kegiatan kepariwisataan yang berlangsung kepada masyarakat secara langsung. Semangat desentralisasi dan pemberian kewenangan penuh bagi warga untuk mengelola pariwisata di daerahnya merupakan hal mutlak untuk terwujudnya pariwisata berbasis komunitas.

Bottom up planning memaksa komunitas lokal untuk berpikir dan bergerak guna merancang dan memutuskan pola pembangunan pariwisata yang memihak kepentingan komunal. Mubyarto (1988) menegaskan bahwa partisipasi merupakan kesediaan membantu berhasilnya program sesuai dengan kemampuan setiap orang tanpa berarti harus mengorbankan kepentingan sendiri. Partisipasi intinya adalah sikap sukarela dari masyarakat untuk membantu keberhasilan program pembangunan. Selain itu, partisipasi juga dapat dimaknai sebagai bentuk keterlibatan mental sekaligus emosional seseorang dalam situasi kelompok yang mendorongnya untuk ikut serta menyumbangkan kemampuan dalam mencapai tujuan kelompok dan ikut bertanggung jawab atas tujuan kelompok, termasuk pelaksanaan program-program tersebut. Pelibatan ini membuat masyarakat merasa memiliki dan bertanggung jawab terhadap proses keberlanjutan program pembangunan. Pendekatan partisipatif yang dilaksanakan diharapkan akan memberikan ruang bagi perkembangan aktivitas yang berorientasi kompetisi dan tanggung jawab sosial oleh anggota komunitas itu sendiri. Pentingnya partisipasi dalam pembangunan memberikan arti bahwa segala hal yang berkaitan dengan pengambilan kebijakan ekonomi, seperti menarik investor luar, maka harus melibatkan warga (Bryson, 1995;2007). Dalam proses pembangunan ekonomi di wilayah pedesaan warga hendaknya tidak saja dijadikan objek, melainkan sebagai subyek dalam menentukan arah perkembangan masyarakat, sehingga jika warga masyarakat menolak investasi yang masuk, maka pemerintah juga tidak dapat memaksakan kehendaknya.

Arnstein (1969:216) menjelaskan bahwa partisipasi warga dapat digambarkan sebagai pendistribusian kekuasaan diantara anggota masyarakat itu sendiri. Lebih lanjut Arnstein memberikan delapan tipologi tingkatan partisipasi masyarakat; manipulasi, terapi, informing, konsultasi, placation, kemitraan, pembagian kekuasan, dan kontrol warga. Sedangkan oleh Pretty (1995) partisipasi masyarakat teridentifikasi menjadi tujuh sesuai dengan derajat tingkatan partisipasi: partisipasi manipulatif, partisipasi pasif, partisipasi dengan konsultasi, partisipasi dalam bentuk material, partisipasifungsional, partisipasi aktif, dan mobilisasi secara mandiri. Lebih lanjut bahwa hakekat dari partisipasi masyarakat merupakan bentuk peningkatan daya tawar bagi masyarakat itu sendiri, sehingga posisinya menjadi seimbang dengan pemerintah ataupun investor. Hal ini juga berfungsi sebagai kekuatan untuk mengontrol kebijakan yang diambil pemerintah agar terjadi sinergi antara sumber daya lokal, kekuatan politik pemerintah, dan sumber daya dari luar atau investor.

Tabel 1 
Tipologi Normatif dalam Partisipasi Masyarakat

\begin{tabular}{|c|c|c|c|}
\hline Level 1 & $\begin{array}{l}\text { 7. Self-mobilization } \\
\text { 6. Interactive participation }\end{array}$ & $\begin{array}{l}\text { 8. Citizen control } \\
\text { 7. Delegated power } \\
\text { 6. Partnership }\end{array}$ & $\begin{array}{l}\text { Spotaneus participation : } \\
\text { - Bottom up } \\
\text { - Active participation } \\
\text { - Direct participation } \\
\text { - Participation in decision making } \\
\text { - Authentic participation } \\
\text { - Self planning }\end{array}$ \\
\hline Level 2 & $\begin{array}{l}\text { 5. Fuctional paticipation } \\
\text { 4. Participation for material incentives } \\
\text { 3. Participation by consultation }\end{array}$ & $\begin{array}{l}\text { 5. Placation } \\
\text { 4. Consultation } \\
\text { 3. Informing }\end{array}$ & $\begin{array}{l}\text { Induced participation : } \\
\text { - Top down } \\
\text { - Passive } \\
\text { - Formal } \\
\text { - Mostly indirect } \\
\text { - Degree of tokenism } \\
\text { - Manipulation } \\
\text { - Pseudo participation } \\
\text { - Participation in implementation and } \\
\text { sharing benefits } \\
\text { - Choice between proposed alternatives } \\
\text { and feedback }\end{array}$ \\
\hline Level 3 & $\begin{array}{l}\text { 2. Passive artisipation } \\
\text { 1. Manipulative participation }\end{array}$ & $\begin{array}{l}\text { 2. Therapy } \\
\text { 1. Manipulation }\end{array}$ & $\begin{array}{l}\text { Coercive participation : } \\
\text { - Top down } \\
\text { - Passive } \\
\text { - Formal } \\
\text { - Mostly indirect } \\
\text { - Participation in implementation but not } \\
\text { necessarily sharing benefits } \\
\text { - Choice between proposed limited } \\
\text { alternatives or no choice } \\
\text { - Paternalism } \\
\text { - Hon participation } \\
\text { manipulation }\end{array}$ \\
\hline Level 4 & $\begin{array}{l}\text { Non-participation } \\
\text { Pretty's (1995) typology of community } \\
\text { participation }\end{array}$ & $\begin{array}{l}\text { Arnstein (1969) } \\
\text { typology of } \\
\text { community } \\
\text { participation }\end{array}$ & $\begin{array}{l}\text { Tosun's (1999) typology of community } \\
\text { participation }\end{array}$ \\
\hline
\end{tabular}

Sumber : diadaptasi dari Tosun(1999)

Pengembangan desa wisata semestinya menerapkan pendekatan community based

tourism. Masyarakat berperan penting dalam menunjang pembangunan pariwisata. Sedangkan keterlibatan pemerintah dan swasta sebatas memfasilitasi masyarakat sebagai pelaku utama pengembangan desa wisata. "Pariwisata dari Rakyat, Oleh Rakyat, dan untuk Rakyat" adalah jargon produk masa pemerintahan Gus Dur yang diproduksi untuk menunjukkan perhatian dan dorongan pemerintah kepada masyarakat dalam membangun kepariwisataan. Nilainilai yang mendasari kepariwisataan tidak lain adalah pariwisata yang dijalankan pemerintah selama ini sudah semestinya memang benar-benar dapat memberikan peran total bagi masyarakat yang ujungnya bermuara pada kesejahteraan rakyat. Sesuai dengan hakikat desa wisata yang semestinya diinisiasi secara intern dan mandiri oleh masyarakat tempatan (lokal) ini berarti bahwa pemerintah, baik tingkat pusat dan daerah hanya sebagai fasilitator. Proses tumbuh dan berkembangnya desa wisata akan bergantung pada masyarakat itu sendiri.

Prinsip-prinsip pariwisata yang berkelanjutan (sustainable tourism) harus mendasari pengembangan desa wisata. Pengembangan yang melampaui daya dukung akan menimbulkan dampak yang besar tidak hanya pada lingkungan alam, tetapi juga pada kehidupan sosial budaya masyarakat yang pada akhirnya akan mengurangi daya tarik desa tersebut. Beberapa bentuk keterlibatan masyarakat tersebut adalah penyediaan fasilitas 
akomodasi berupa rumah-rumah penduduk (home stay), penyediaan kebutuhan konsumsi wisatawan, pemandu wisata, penyediaan transportasi lokal, pertunjukan kesenian, dan lain-lain.

Pengembangan desa wisata merupakan bagian dari penyelenggaraan pariwisata yang terkait langsung dengan jasa pelayanan yang membutuhkan kerjasama dengan berbagai komponen penyelenggara pariwisata yaitu pemerintah, swasta, dan masyarakat. Upaya membangun pariwisata dengan cara mendorong peran masyarakat menjadi hal vital. Senada dengan ini disampaikan Greffe (1994) dan Gannon (1994) yang menyebutkan bahwa bila pariwisata pedesaan tidak dilandasi oleh perencanaan yang matang, berbagai hal negatif akan terjadi dan dapat mengancam keberlanjutan sumber daya di kawasan pedesaan itu sendiri. Daerah pedesaan dengan berbagai keunikannya, seperti lingkungan yang alami, pemandangan dan bentang alam yang indah, beraneka ragam tumbuhan, masyarakat pedesaan, dan pola hidup mereka yang khas merupakan alternatif untuk memberikan pengalaman 'lain' kepada wisatawan dan sekaligus untuk mendiversifikasi produk wisata (Lane, 1994). Berbagai keunikan tersebut telah mendukung berkembangnya pariwisata minat khusus yang lebih dikenal dengan pariwisata pedesaan atau rural tourism. Inskeep (1991) menyebutkan bahwa pariwisata pedesaan "...refers to tourist staying in or near a village, often traditional village in remote areas, learning about the village0 and local cultural way of life and customs, and often participating in some village activities (Chuang dalam Damanik, tt, 2010:1313 dan Kuvacic, dkk dalam Damanik, tt, 2010:1648) memaknai pariwisata perdesaan dengan menunjukkan suatu lingkungan geografis tempat terjadi/ berlangsungnya aktivitas pariwisata dan karakteristik asli berupa budaya tradisional, budaya pertanian, lanskap pedalaman, dan gaya hidup sederhana. Konteks ruang (space) menjadi penting untuk memosisikan aktivitas dan implikasi perkembangan pariwisata perdesaan. Desa wisata merupakan bentuk alternatif pariwisata yang mampu menyumbang perubahan-perubahan positif terhadap sumberdaya sosial, ekonomi, dan budaya di daerah perdesaaan (Damanik,tt).

\section{PEMBAHASAN}

Pengembangan untuk menjadi desa wisata memerlukan kerjasama dan keikutsertaan seluruh masyarakat desa guna memajukannya. Selain itu dalam pengembangan desa wisata memerlukan perencanaan matang sehingga dapat menjadi salah satu objek wisata sehingga menjadi kenangan bagi wisatawan (Permanasari, 2010:64). Segenap program pembangunan termasuk sektor kepariwisataan, seperti yang dijalankan masyarakat di dataran tinggi Dieng diawali dengan perencanaan. Perencanaan pariwisata yang dikerjakan lewat metode partisipatif dengan pelibatan masyarakat secara penuh dalam prosesnya sehingga perencanaannya lebih didasarkan pada kajian-kajian terhadap masalah yang mereka hadapi serta potensi yang tersedia di dalam masyarakat. Metode ini diharapkan akan terjalin hubungan antara masyarakat dengan kelembagaan wisata secara terus menerus. Masyarakat diberi kesempatan untuk menyatakan masalah yang dihadapi dan gagasan-gagasan sebagai masukan untuk berlangsungnya proses perencanaan berdasarkan kemampuan warga masyarakat desa. Itulah makna perencanaan partisipatif. Bila model perencanaan dengan melibatkan segenap warga mencoba menfungsikan kelembagaan setempat secara nyata di dalam menyusun perencanaan pembangunan, khususnya di sektor pariwisata, maka diharapkan masyarakat sanggup melaksanakan, memelihara, dan menindaklanjuti hasil-hasil pembangunan. Bilamana proses perencanaan partisipatif itu dapat berlangsung, maka diharapkan akan mampu meningkatkan peran serta masyarakat, yang berarti pula memberdayakan masyarakat dalam pembangunan desanya.

Melalui riset aksi ini, masyarakat Dieng Kulon diajak melakukan teknik perencanaan 
partisipatif. Dua teknik yang dijalankan, yaitu (a) pemetaan partipatif (participatory mapping) dan (b) menyusun diagram venn hubungan antar-lembaga. Pada teknik pertama dimaksudkan untuk menghasilkan mapping yang meliputi: (i) identifikasi permasalahan, (ii) identifikasi potensi sumberdaya dan peluang pengembangannya, serta (iii) identifikasi potensi pariwisata. Metode yang diterapkan adalah dengan focus group discussion (FGD). Diskusi terfokus dilaksanakan bersama elemen masyarakat meliputi pengelola wisata, perwakilan pengurus desa, dan tokoh masyarakat. Secara gender forum ini juga dihadiri kaum perempuan dan laki-laki. Kegiatan pertemuan dijalankan secara informal dipandu fasilitator. Dalam FGD ini diawali dengan uraian maksud dan tujuan pertemuan yang disampaikan fasilitator. Target dari pertemuan ini adalah diperoleh kesadaran bersama (collectives awarness) akan potensi beserta peluang pengembangan pariwisata berbasis pedesaan yang dimungkinkan dapat dijalankan di wilayah Desa Dieng Kulon khususnya dan Dieng Plateau pada umumnya. Dari rembug bersama diperoleh informasi bahwa dibandingkan tiga empat tahun lampau, ekonomi pariwisata di Dieng Kulon baru diawali dengan beberapa homestay. Homestay merupakan salah satu sarana penunjang pariwisata yang dikelola dengan konsep community based tourism (CBT), artinya masyarakat (pemilik) secara mandiri dan swadaya menyiapkan sebagian kamar dari rumah tinggalnya sebagai tempat inap sementara. Jalinan interaksi sosial yang lebih ditekankan dibandingkan sekedar hubungan bisnis, antara tamu dan tuan rumah.

Homestay yang dikembangkan dengan memanfaatkan beberapa ruang kamar untuk disewakan kepada wisatawan yang karena faktor cuaca memaksa mereka tidak mungkin melanjutkan perjalanan pulang. Daerah Dieng Kulon hanya ada satu hotel yang berdiri, yaitu hotel Gunung Mas. Bila peak season hotel tidak sanggup menampung tamu sehingga muncul inisiatif beberapa keluarga untuk membuka rumahnya sebagai homestay. Ajakan pihak
Pemerintah, dalam hal ini Dinas Pariwisata Banjarnegara, ternyata telah menyadarkan warga Dieng Kulon bahwa selain pertanian, warga Dieng masih mendapatkan sesuatu usaha lain, yaitu usaha jasa pariwisata yang dijalankan (homestay). Kini berbagai usaha ekonomi penopang aktivitas pariwisata sudah mulai bergairah dijalankan oleh warga Dieng Kulon. Bukan saja homestay yang awalnya di bawah 10 buah dan kini berkembang lebih menjadi 40 rumah inap telah berjalan. Informasi di akhir tahun 2012 di Dieng Kulon semakin marak perkembangan homestay hingga mendekati 50 buah, dengan berbagai klasifikasi dan fasilitas yang disiapkan masingmasing pemilik. Secara ekonomi memang tampak ada perbaikan dan peningkatan dari adanya kegiatan pariwisata di dataran tinggi Dieng. Kondisi ini menjadikan sebagian dari warga yang tadinya hanya petani kentang juga mulai merambah bisnis homestay sebagai alternatif inkam tambahan. Selain itu di sekitar desa juga sudah banyak warga membuka warung makan, seperti warung nasi padang, nasi rames, warung sate madura, dan warung kelontong yang menjadikan kemudahan bagi wisatawan untuk berbelanja.

Gagasan untuk belajar bersama warga Dieng Kulon guna mengelola potensi yang ada di desanya coba dijalankan lewat pertemuan bersama. Peran fasilitator mengajak bersama untuk merefleksikan dan merancang desa wisata secara kolektivitas. Beberapa proses dilakukan dengan cara mengajak warga untuk melakukan beberapa tahap sebagai berikut.

\section{Identifikasi Permasalahan: Perspektif Lokal}

Upaya mengenali "potensi diri" yang sudah dilakukan secara mandiri merupakan langkah awal yang produktif dilakukan warga Dieng Kulon. Dapat diibaratkan bahwa serpihan-serpihan potensi daya tarik yang terdapat di Dieng Kulon sebagai akar-akar dari sebuah pohon. Itu semua merupakan dasar bagi tumbuhnya batang dan daun serta buah hasil dari sektor pariwisata. Akar pariwisata; seperti kesenian, 
kerajinan makanan dan non-makanan, aktivitas pertanian, permainan anak/ tradisonal merupakan daya tarik yang dapat dikemas sebagai aset wisata kerakyatan. Akar-akar yang kuat dapat dihasilkan dan dikembangkan secara profesional, bila akar-akar wisata yang diibaratkan tersebut ditopang/didukung dengan batang pohon yang kokoh. Batang pohon inilah yang berfungsi untuk mengarahkan, mengelola, dan mengemas akar-akar wisatanya agar lebih memiliki daya saing. Batang pohon diwujudkan melalui lembaga wisata lokalsemacam Kelompok Sadar Wisata (Pokdarwis) yang didorong pemerintah agar di setiap kecamatan atau kawasan wisata dibentuk Kelompok Sadar Wisata (Pokdarwis). Pokdarwis merupakan lembaga sosial yang dibentuk secara bottom up, atas inisiatif warga untuk secara serius mengelola wisata yang terdapat di daerahnya.

Adanya kesadaran dalam melihat diri dan lingkungannya merupakan bekal dasar untuk lebih serius menjalankan usaha pariwisata di desa tersebut. Akan tetapi, untuk sebuah langkah yang baru bahwa dari ekonomi pertanian ke ekonomi jasa, tentunya tidak semudah membalik tangan. Warga pun diajak secara kritis mengidentifikasi berbagai permasalahan secara internal dan eksternal yang secara realitas dihadapinya. Dari diskusi yang dilaksanakan, maka diperoleh gambaran permasalahan sebagai berikut ini.

Tabel. 2

Klasifikasi Permasalahan di Dieng Kulon Perspektif Masyarakat

\begin{tabular}{|c|c|}
\hline Aspek & \multirow{2}{*}{ Masalah yang Dihadapi } \\
\hline Aspek Internal & \\
\hline $\begin{array}{l}\text { SDM pendukung } \\
\text { wisata }\end{array}$ & $\begin{array}{l}\text { Masih dominannya pola pikir } \\
\text { sebagai petani dibandingkan } \\
\text { sebagai penyedia jasa. } \\
\text { Belum memasyarakatnya sadar } \\
\text { wisata/ sapta pesona } \\
\text { Terbatasnya kesempatan mengikuti } \\
\text { pelatihan-pelatihan bidang } \\
\text { pariwisata }\end{array}$ \\
\hline $\begin{array}{l}\text { Kelembagaan } \\
\text { Wisata Lokal }\end{array}$ & $\begin{array}{l}\text { Belum pahamnya pengelola di } \\
\text { pokdarwis akan tupoksinya } \\
\text { Minimnya akses dan jejaring yang } \\
\text { dimiliki pengelola }\end{array}$ \\
\hline Aspek Eksternal & \\
\hline
\end{tabular}

\begin{tabular}{|l|l|}
\hline Aksesibilitas & $\begin{array}{l}\text { Jalan menuju kawasan Dieng Kulon } \\
\text { tidak memungkinkan di lewati bis } \\
\text { besar }\end{array}$ \\
& $\begin{array}{l}\text { Ada sebagian jalan ke beberapa } \\
\text { objek yang rusak parah } \\
\text { Jalan setapak ke Candi Dwarawati } \\
\text { terganggu pralon yang malang } \\
\text { melintang } \\
\text { Jalan ke objek sempit, sehingga sulit } \\
\text { untuk bersimpangan mobil }\end{array}$ \\
\hline Sarana & $\begin{array}{l}\text { Atraksi dimalam hari belum dapat } \\
\text { dikembangkan }\end{array}$ \\
\hline Penunjang Wisata & $\begin{array}{l}\text { Perbukitan didimonasi tanaman } \\
\text { kentang, rentan longsor. } \\
\text { Tingginya intensitas pemakaian } \\
\text { pupuk kimia } \\
\text { Penurunan kualitas tanah } \\
\text { yang berimbas pada turunnya } \\
\text { produktivitas tanaman kentang }\end{array}$ \\
\hline
\end{tabular}

Sumber : Dikembangkan dari data primer, 2010

Dari tabel permasalahan di atas, masyarakat melihat dalam mendorong perkembangan pariwisata khususnya di Dieng Kulon dan umumnya di dataran tinggi Dieng terdapat kendala internal dan eksternal yang krusial dan segera perlu diberikan solusi guna mendorong perkembangan desa wisata Dieng Kulon yang terus berjalan. Harapannya adalah pihak pemerintah selaku fasilitator, dapat mencermati dan memberikan solusi lebih lanjut. Fakta ini memperlihatkan pula bila upaya pembangunan desa wisata bukan saja akan berhasil jika dikelola oleh masyarakat, tetapi memerlukan support pihak pemerintah, dalam hal regulasi dan perbaikan infrastruktur serta dukungan pihak swasta dibidang lainnya. Bila koordinasi dapat dilakukan mestinya akan terjadi percepatan dalam pengembangan pariwisata Dieng Kulon dan sekitarnya.

\section{Mapping Potensi Sumberdaya Wisata}

Tahap selanjutnya, berbagai potensi sumberdaya yang terdapat di Dieng Kulon, maka hasil curah gagasan bersama ini diketahui adanya klasifikasi sumberdaya yang melingkupi daerahya yang mencakup komponen fisik, biotik, dan sosial budaya, seperti tampak ditabel berikut ini. 
Tabel. 3

Klasifikasi Potensi Dieng Plateau dan Peluang Pengembangannya

\begin{tabular}{|l|l|l|}
\hline Komponen & \multicolumn{1}{|c|}{ Potensi Daya Tarik } & \multicolumn{1}{c|}{ Peluang Yang Dapat Dikembangkan } \\
\hline \multirow{5}{*}{ Fisik/Alam } & Landscape Perbukitan & Tracking, outbond, pemandu wisata \\
\cline { 2 - 3 } & Kawah & Persewaan binokuler, pemandu wisata \\
\cline { 2 - 3 } & Air terjun & Outbond, tracking, pemandu wisata \\
\cline { 2 - 3 } & Telaga & Persewaan alat pancing,wisata air (perahu) \\
\cline { 2 - 3 } & Kompleks percandian & Area penjualan hasil bumi khas Dieng. \\
\hline \multirow{3}{*}{ Biotik/Vegetasi } & Tanaman Carica & Demplot kebun Carica, Usaha olahan Carica \\
\cline { 2 - 3 } & Tanaman Khas Purwaceng & Demplot kebun Purwaceng, Usaha olahan Purwaceng \\
\cline { 2 - 3 } Living Culture & Terong Belanda & Demplot kebun terong Belanda, Usaha olahan terong Belanda \\
\cline { 2 - 3 } & Jambu Bunut & Semplot kebun Jambu bunut \\
\hline & $\begin{array}{l}\text { Tari Rampak Yakso, Ruawatan } \\
\text { cukur rambut anak gimbal }\end{array}$ & $\begin{array}{l}\text { Mengemas paket pertunjukan budaya } \\
\text { Mendirikan sanggar tari } \\
\text { Mengaktifkan event budaya khas Dieng }\end{array}$ \\
\cline { 2 - 3 } & Situs budaya Museum & $\begin{array}{l}\text { Wisata edukasi : sejarah, arkeologi dan budaya Dieng dan } \\
\text { pendidikan energy tentang geothermal }\end{array}$ \\
\hline
\end{tabular}

Sumber : Dikembangkan dari data primer, 2010

Dari tabel di atas ternyata ada "kesadaran kolektif" atas potensi yang dapat dikembangkan, bukan saja membuka homestay semata. Atas kesadaran yang dimiliki inilah akan memudahkan untuk mengajak warga merencanakan model desa wisata yang sesuai prinsip lokalitas. Sekaligus mendorong peranserta serta kesiapan warga desa untuk menjadi pelaku usaha jasa, bukan saja berprofesi sebagai petani kentang. Warga pun diajak berpikir bahwa aktivitas yang ke depan dapat dikembangkan bukan saja mengandalkan objek-objek juga khas Dieng, seperti telaga, candi dan kawah, tetapi dengan mengajak wisatawan on site ke kebun kentang, ke dapur, ke tegalan, dan lainnya sehingga ada integrasi antara sektor pertanian dan sektor pariwisata. Ini berarti masuknya pariwisata di desa-desa bukan menggantikan aktivitas ekonomi utama warga, tetapi justru memberikan alternatif tambahan bagi rumah tangga petani dari sektor jasa ini. Bagi wisatawan sendiri, selama mereka tinggal di homestay serta bergaul dan ikut menyelami kehidupan petani Dieng, mereka akan mendapatkan pengalaman batin baru yang sebelumnya belum pernah dialaminya.

Dalam pengembangan desa sebagai objek wisata perlu dipahami sejak awal bila masyarakat setempat bukan objek yang pasif namun justru sebagai subjek yang aktif. Sebuah lingkungan perdesaan dapat dipandang sebagai objek sekaligus subyek wisata. Sebagai objek, artinya desa tersebut merupakan tujuan kegiatan pariwisata, sedangkan sebagai subyek adalah sebagai penyelenggara, apa yang dihasilkan oleh desa akan dinikmati oleh masyarakatnya secara langsung dan peran aktif masyarakat sangat menentukan kelangsungannya (Soebagyo,1991 dalam Raharjana, 2005). Kegiatan yang akan terjalin interaksi wisatawan sebagai tamu dengan masyarakat selaku tuan rumah akan menimbulkan pengalaman budaya.

Uraian kegiatan interaksi budaya tersebut dapat terjalin dalam kegiatan sosial kemasyarakatan, kegiatan hunian masyarakat, baik yang bersifat pribadi ataupun komunal, kegiatan pembinaan, dan pengelolaan untuk memberikan peningkatan sumberdaya manusia dalam hal ketrampilan serta aspek pengelolaan administrasi bagi kegiatan desa ataupun kegiatan wisata itu sendiri, dan terakhir adalah kegiatan wisata. Kegiatan wisata dapat mencakup atraksi dan akomodasi. Kegiatan yang dapat dijadikan atraksi antara lain; kegiatan upacara tradisional, kegiatan kesenian desa, kegiatan olah raga, kegiatan makan-minum, dan lainnya. Sementara untuk akomodasi yang diperlukan untuk tempat tinggal wisatawan yang berkeinginan menetap untuk sementara waktu juga patut diperhatikan. Beberapa tempat tinggal khas yang memungkinkan dapat dikembangkan sebagai sarana 
akomodasi dengan melakukan perbaikan, menjaga kebersihan sehingga memenuhi standar minimal akomodasi jika dilihat dari segi kesehatan dan kenyamanan, mencakup sirkulasi udara, penyinaran, sanitasi, dan penyediaan sarana MCK.

\section{Pemetaan Partisipatif tentang Atraksi Wisata}

Untuk menghasilkan pemetaan atraksi di desa wisata dipakai metode PRA yang dikerjakan bersama warga. Dipahami bersama bahwa hal yang mendorong terjadinya aktivitas wisata adalah ketersediaan objek/ atraksi wisata. Something to see berupa atraksi harus tersedianya agar dapat dijadikan objek wisata. Demikian halnya dengan apa yang dapat disajikan/ditawarkan bagi wisatawan saat mereka live in di homestay. Melalui diskusi bersama warga tampak adanya pemahaman warga desa terkait dengan titik-titik atau objek wisata yang menjadi daya tarik selama ini serta sebaran potensi yang dapat diangkat sebagai daya tarik berbasis pertanian di desa Dieng Kulon. Desa Dieng Kulon yang termasuk dalam kawasan "poros" pariwisata Dieng Plateau sebetulnya memilik posisi yang strategis ditunjang lagi dengan keberadaan sarana penunjang pariwisata yang sebagian berada di wilayahnya, seperti sub terminal, kompleks Candi Arjuna, warung-warung, gedung pertemuan Withliem, dan sarana lainnya. Dapat disebutkan bila area kompleks Candi Arjuna ini sebagai "titik nol" dari awal mula pusat pelayanan wisata untuk area Dieng Plateau.

Hasil diskusi bersama diketahui bahwa warga memiliki pemahaman akan sumberdaya/daya tarik yang sering dikunjungi wisatawan atau tempat-tempat di mana para pemandu lokal sering mengajak wisatawannya, seperti ke Candi Arjuna, Bale Kambang, Museum Kailasa, Candi Bima, dan Kawah Sikidang. Telaga Merdada dan objek alam lainnya yang masih masuk wilayah Kab. Banjarnegara. Selain itu dari hasil mapping atraksi wisata ini juga diperoleh adanya pengetahuan mengenai potensi alternatif daya tarik yang terdapat di wilayah kampung atau dengan memanfaatkan sumberdaya pertanian lokal di sana untuk diangkat sebagai atraksi wisata. Jenisnya mencakup pertanian purwaceng, pertanian jambu bunut, terong Belanda, perternakan Dodi-Domba Dieng yang bercirikan bulunya yang tebal, termasuk juga sentra atraksi pembuatan keripik kentang, asinan Carica, dan sebagainya. Hasil mapping bersama warga selanjutnya diolah dan ditampilkan secara grafis sehingga menjadi map sebaran daya tarik objek wisata area Dieng Plateau dan Desa Dieng Kulon, seperti tersaji berikut ini.

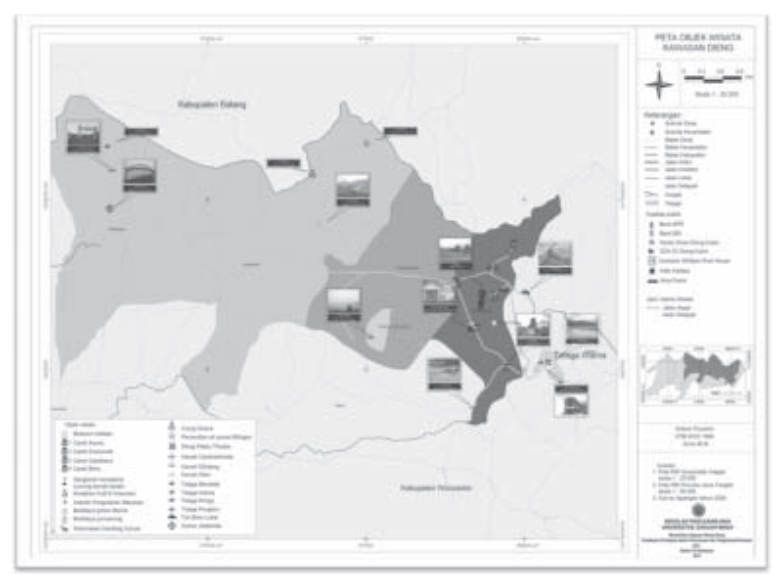

Gambar. 1

Mapping Daya Tarik Wisata Desa Wisata Dieng Kulon

\section{Pemetaan Matriks Hubungan Antarlembaga}

Langkah ini dimaksudkan untuk memberikan pemahaman bahwa dalam membangun pariwisata bukan semata tanggungjawab masyarakat semata, tetapi melalui kerjasama dan kemitraan yang dapat dikembangkan akan mendorong percepatan pelaksanaan pembangunan pariwisata. Termasuk juga di lingkungan perdesaan Dieng Kulon. Untuk saat ini dari identifikasi yang berhasil dikembangkan, masyarakat desa Dieng Kulon juga telah membentuk lembaga pengelola pariwisata yang mereka beri nama Dieng Pandawa. Kelompok Sadar Wisata (Pokdarwis) demikian lembaga ini berfungsi sebagai mitra pemerintah dan menjadi fasilitator dalam pelaksanaan dan monitoring aktivitas pariwisata yang berlangsung di kawasan Dieng, khususnya 
yang termasuk di wilayah Kec. Batur Kab. Banjarnegara. Awalnya motivasi untuk menata dan membangun kegiatan wisata lebih berorientasi ke wisata pertanian dilaksanakan warga Dieng Kulon memang masih dapat dikatakan "embrio" termasuk juga dengan terbentuknya Kelompok Sadar Wisata (Pokdarwis) yang diberi nama Dieng Pandawa. Adapun kelompokkelompok kegiatan yang tergabung dalam Pokdarwis adalah sebagai berikut ini.

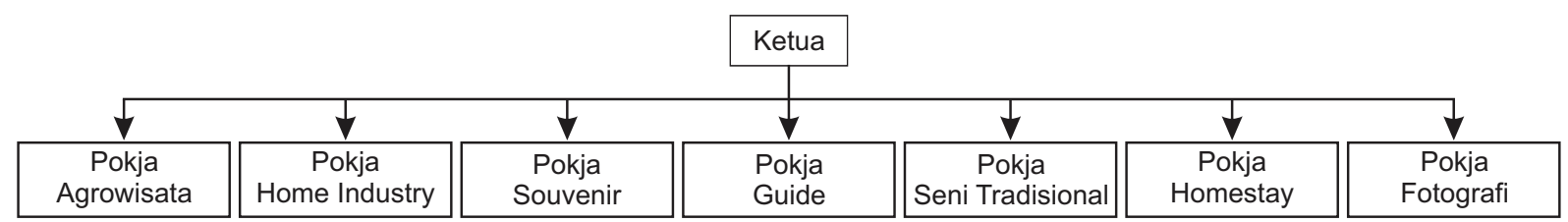

Gambar.2

Struktur Kepengurusan Pokdarwis Dieng Pandawa Desa Wisata Dieng Kulon

Selain Pokdarwis dari diskusi bersama warga juga dihasilkan identifikasi lembaga-lembaga lainnya yang ternyata memiliki keterkaitan baik langsung atau tidak dengan masyarakat di desa Dieng Kulon. Bila dicermati lebih lanjut dapat disajikan dalam matriks sebaga berikut ini.

Tabel. 4

Keterlibatan Pihak di Desa Wisata Dieng Kulon

\begin{tabular}{|c|c|c|c|c|}
\hline \multicolumn{5}{|c|}{ Lembaga-Lembaga Terkait } \\
\hline $\begin{array}{c}\text { Dinas Pariwisata Prov } \\
\text { Jawa Tengah }\end{array}$ & $\begin{array}{c}\text { Dinaspar Kab } \\
\text { Banjarnegara \& } \\
\text { UPTD Dieng }\end{array}$ & Kementerian Pusat & Perguruan Tinggi & $\begin{array}{l}\text { Pihak } \\
\text { Swasta }\end{array}$ \\
\hline $\begin{array}{l}\text { Memberikan alokasi } \\
\text { dan dukungan dana } \\
\text { untuk peningkatan } \\
\text { SDM pelaku wisata } \\
\text { lokal }\end{array}$ & $\begin{array}{l}\text { Menjadi mitra bagi } \\
\text { pengelola desa wisata } \\
\text { di Dieng Kulon }\end{array}$ & $\begin{array}{l}\text { Tahun } 2010 \\
\text { memberikan } \\
\text { dukungan dalam } \\
\text { bentuk pemberian } \\
\text { dana hibah melalui } \\
\text { PNPM Pariwisata di } \\
\text { desa Dieng Kulon dan } \\
\text { dua lainnya sekitar } \\
\text { desa Dieng Kulon. } \\
\text { Melibatkan Dieng } \\
\text { Kulon dalam event di }\end{array}$ & $\begin{array}{l}\text { UGM melaksanakan } \\
\text { kajian perencanaan } \\
\text { pembangunan desa } \\
\text { wisata di Dataran } \\
\text { Tinggi Dieng dengan } \\
\text { dana dari pihak } \\
\text { Kemenbudpar (2008) }\end{array}$ & $\begin{array}{l}\text { Memberikan } \\
\text { dukungan dalam } \\
\text { bentuk peliputan/ } \\
\text { reportase yang } \\
\text { dilaksanakan pihak } \\
\text { televisi swasta } \\
\text { nasional dengan cara } \\
\text { shotting di kawasan } \\
\text { Dieng sehingga turut } \\
\text { mempromosikan } \\
\text { Dieng }\end{array}$ \\
\hline $\begin{array}{l}\text { Melaksanakan event } \\
\text { lomba/kejuruan } \\
\text { yang diikuti seluruh } \\
\text { desa wisata se-Jawa } \\
\text { Tengah }\end{array}$ & $\begin{array}{l}\text { Memberikan } \\
\text { rekomendasi } \\
\text { dan fasilitasi } \\
\text { pengembangan } \\
\text { fisik dan non- fisik } \\
\text { kawasan Wisata } \\
\text { Dieng yang termasuk } \\
\text { wilayah Kab. } \\
\text { Banjarnegara }\end{array}$ & & $\begin{array}{l}\text { Pihak UGM } \\
\text { melaksanakan KKN } \\
\text { tematik Pariwisata } \\
\text { selama } 3 \text { mulai tahun } \\
2009\end{array}$ & $\begin{array}{l}\text { Memberikan } \\
\text { dukungan material } \\
\text { dalam kegiatan } \\
\text { social/pariwisata } \\
\text { dan budaya yang } \\
\text { berlangsung di } \\
\text { desa Dieng Kulon. } \\
\text { Pihak swasta, seperti } \\
\text { PT Geodipa, dan } \\
\text { kalangan perusahaan } \\
\text { rokok juga pernah } \\
\text { memberikan } \\
\text { dukungan }\end{array}$ \\
\hline
\end{tabular}

Sumber : Dikembangkan dari data primer, 2010

\section{SIMPULAN}

Kajian partisipatif menerapkan (participatory pendekatan Penerapannya secara khusus diterapkan pada desa wisata di dataran tinggi Dieng, tepatnya Desa Dieng Kulon Kec. Batur Banjarnegara. Kajian berangkat dari asumsi bahwa keberhasilan pembangunan apapun bentuknya, termasuk pariwisata sudah 
semestinya melibatkan masyarakat sebagai subjek. Warga setempat diberi hak mutlak untuk ikut menentukan masa depan. Selain itu lewat penerapan metode ini agar tidak ada terjadi kegagalan model pembangunan sebelumnya yang cenderung tidak partisipatif. Oleh karenanya, model kerja partisipatif dalam pendekatan ini dipandang strategis memperbaiki proses perencanaan sebelumnya, atau mengedepankan proses belajar dari dan bersama masyarakat setempat. Dari hasil dialog bersama warga desa Dieng Kulon yang ditunjang dengan berbagai metode pengumpulan data, baik partisipasi observasi, wawancara sambil lalu serta melaksanakan pertemuan kelompok.

Dari proses riset aksi ini diperoleh rumusan bahwa eksistensi Dieng Plateau sebagai destinasi nasional bahkan internasional masih mampu menyedot perhatian para pelancong. Meskipun model wisata konvensional dalam bentuk massif tourism- masih mendominasi, tetapi tidak menutup peluang menangkap pewisata minat khusus yang tertarik untuk belajar lebih dekat kehidupan masyarakat desa. Adanya motivasi dan dorongan secara kolektif dari sebagian warga di desa Dieng untuk mengelola pariwisata sebagai respon atas semakin tidak menentunya hasil dari pertanian. Ditingkat komunitas, sudah terbentuk pengelola pariwisata berbasis desa. Kajian ini pula telah melahirkan model perencanaan partisipatif yang hasilnya antara lain dipahaminya berbagai potensi dan permasalahan yang melingkupi perkembangan pariwisata di Dieng, serta diketahuinya hubungan peran dan fungsi antarlembaga yang dpandang memberikan kontribusi bagi pariwisata di Dieng Kulon khususnya dan Dieng Plateau pada umumnya.

\section{DAFTAR PUSTAKA}

Arnstein RS, 1969, "A Ladder of Citizen Participation", Journal of the American Institute of Planners 35: 216-224.

Beeton, S., 2006, Community Development Through Tourism, Australia:
Landlinks Press.

Bryson, J. M., 1995, Strategic Planning for Public and Non Profit Organizations : A guide to Strengthening and Sustaining Organizational Achievement, JosseyBass Publishers: San Francisco.

, 2007, Perencanaan Strategis bagi Organisasi Sosial (terj),Yogyakarta: Pustaka Pelajar.

Chambers, R., 1997, PRA: Memahami Desa Secara paritisipatif, Yogyakarta: Kanisius.

Damanik, J., 2009, "Isu-Isu Krusial Dalam Pengelolaan Desa Wisata Dewasa Ini", Jurnal Kepariwisataan Indonesia 5 (3): 127-137.

,tt, Negara sebagai Sponsor Pengembangan Desa Wisata, kertas kerja.

Lane, 1994, "What is Rural Tourism", Journal of Sustainable Tourism, 2:7-21.

Mowforth, M. dan Ian Munt, 1998, Tourism and Sustainability: New Tourism in the Third World, London: Routledge.

Mubyarto, 1988, Sistem dan Moral Ekonomi Pancasila, Jakarta: LP3ES.

Paramita, M., 1999, “Re-Orientasi \& Rekayasa Bio-Diversity (Green Tourism) Terhadap Pengembangan Produk Wisata", makalah Diskusi Panel "Pembangunan Kepariwisataan Terhadap Isu Lingkungan", Dies Natalis Sekolah Tinggi Pariwisata Bandung ke-35.

Permanasari, I., 2010, “Pengentasan Kemiskinan Melalui Pemberdayaan Masyarakat di Desa Wisata", Jurnal Kepariwisataan Indonesia 5 (1): 57-69.

Pretty J, 1995, “The Many Interpretations of Participations", Focus 16:4-5.

Sonjaya, J. A., 2005, "Pengelolaan Warisan Budaya di Dataran Tinggi Dieng", Tesis. Program Pascasarjana, Fakultas Ilmu Budaya UGM, Tidak dipublikasikan. 
Sukatno, O., CR, 2004, Dieng Poros Dunia : Menguak Jejak Peta Surga yang Hilang. Yogyakarta : IRCiSOD.

Raharjana, D. T., 2005, Pengembangan Desa Wisata Berbasis Budaya: Kajian Etnoekologi Masyarakat Dusun Ketingan, Tirtoadi, Mlati Sleman DIY, Tesis Master, Program Studi Ilmu Lingkungan Sekolah Pascasarjana Universitas Gadjah Mada, Yogyakarta, Tidak dipublikasikan.

Smith dan Eadington, 1992, Tourism and Alternatives, Philadelphia: University of Pennsylvania Press.

Tosun C, 1999, “Towards a typology of community participation in the tourism development Process", International Journal of Tourism and Hospitality 10:113-134.

Weiler dan Hall. M.C., 1992, "Introduction: What's Special About Special Interest Tourism", dalam Special Interest Tourism, London: Belhaven Press.
Kedaulatan Rakyat, 12 Maret 2003, “Dataran Tinggi Dieng Pasca Reformasi (1): Telaga dan Satwa Liar ikut 'Menghilang'", halaman 7.

Kedaulatan Rakyat, 13 Maret 2003, "Dataran Tinggi Dieng Pasca Reformasi (2): Petani Nekad tanam Kendang di Area Hutan", halaman 7.

Kedaulatan Rakyat, 12 April 2008, “Menata Objek Wisata, Menjual Legenda Dieng", halaman 11.

Kompas, 15 September 2003, “Dieng berpotensi sebagai Daerah Tujuan Wisata Internasional", halaman. 17.

Kompas, 23 Desember 2009, "harapan Baru Menyelamatkan Dieng", Teropong, halaman, 40.

Kompas, 3 April 2010, “Dieng: Krisis Air akibat Pestisida", halaman. 23.

Suara Merdeka, 20 Desember 2004, "Bencana di Wonosobo dan Dieng", halaman. 1. 